\title{
KEUNGGULAN KOMPETITIF DAN KOMPARATIF KEMITRAAN \\ INDUSTRI DAN RAKYAT UNTUK MEMBANGUN HUTAN DI PULAU JAWA
}

\section{(Competitive and Comparative Advantages of Partnership between Wood-} processing Industries and Communities on Forest Development in Java Island)

\author{
Oleh/By : \\ Nandang Prihadi ${ }^{1}$, Bramasto Nugroho ${ }^{2}$, Dudung Darusman ${ }^{3}$, Nurheni Wijayanto ${ }^{4}$ \\ ${ }^{1)}$ Program Studi Ilmu Pengetahuan Kehutanan, Sekolah Pascasarjana, Institut Pertanian Bogor, Kampus \\ IPB Darmaga Bogor 16680, Tel. 0251 8425044, \\ Fax.02518621256, e-mail: nandpri@yahoo.com \\ ${ }^{2,3,4}$ Dosen, Fakultas Kehutanan dan Sekolah Pascasarjana, Institut Pertanian Bogor, Kampus IPB \\ Darmaga Bogor 16680, Tel 0251 8425044, Fax 0251 8621256, e-mail: ${ }^{2}$ bramasto2001@yahoo.co.id \\ 3)ddarusman@yahoo.co.id nurheniw@indo.net.id
}

\begin{abstract}
This study is intended to analyse competitive and comparative advantages of partnership between wood-processing industries and communities on plantation forest development (Kibarbut) in Java Island, and its implication on export opportunity. The study was conducted in 3 locations (Sukaraja, Bawang, dan Krucil) in April-October 2008. The study concluded that Kibarbut in Java Island had competitive and comparative advantages. Kibarbut produced commodities (log) which had export opportunities reflected on its competitive's FOB price on world log-market. The study recommended that log export policy of fast growing species (esp. Sengon) harvested from Kibarbut should be implemented.
\end{abstract}

Keywords: Advantages, log export, Java Island, partnership, plantation forest development, wood-processing industries

\begin{abstract}
ABSTRAK
Penelitian ini bertujuan untuk mengetahui keunggulan kompetitif dan komparatif pelaksanaan kemitraan industri pengolahan kayu bersama rakyat untuk membangun hutan (Kibarhut) di Pulau Jawa, dan implikasinya terhadap peluang ekspor kayu hasil Kibarhut. Penelitan dilakukan di 3 Kecamatan (Sukaraja, Bawang, dan Krucil) pada April-October 2008. Hasil penelitian menunjukkan bahwa Kibarhut di Pulau Jawa terbukti memiliki keunggulan kompetitif dan komparatif, serta mempunyai peluang ekspor karena menghasilkan kayu dengan harga FOB yang kompetitif di pasar internasional. Rekomendasi penelitian ini adalah bahwa kebijakan membuka keran ekspor kayu jenis kayu tumbuh cepat (khususnya jenis sengon) adalah memungkinkan untuk dilakukan
\end{abstract}

Kata kunci: Ekspor kayu, industri pengolahan kayu, keunggulan, kemitraan, pembangunan hutan, Pulau Jawa

\section{PENDAHULUAN}


Pengembangan Hutan Tanaman Industri (HTI) melalui skema HPHTI (Hak Pengusahaan Hutan Tanaman Industri) telah dimulai sejak tahun 1986 (SK Menhut No. 320/Kpts-II/1986 dan PP No. 7 Tahun 1990). Pembangunan HTI bertujuan untuk menunjang pertumbuhan industri perkayuan melalui penyediaan bahan baku dalam jumlah dan kualitas yang memadai dan berkesinambungan. Sesuai dengan tujuannya, maka pembangunan HTI diharapkan dapat menyediakan pasokan bahan baku bagi keperluan industri, baik industri pertukangan maupun industri pulp andpaper.

Pembangunan hutan tanaman juga dilakukan pada lahan milik secara swadaya oleh petani maupun kemitraan dengan melibatkan berbagai pihak, di antaranya dengan industri pengolahan kayu bundar (INPAK) atau industri pengolahan kayu bahan baku serpih ( $p$ ulp and paper). Kerjasama ekonomi tersebut dilakukan petani dan para pemilik lahan untuk mengatasi kendala permodalan dan akses pasar, sekaligus upaya mengoptimalkan faktor produksi milik petani.

Pada sisi lain, kelangkaan pasokan kayu bundar (dari hutan alam) mendorong beberapa INPAK untuk melakukan inovasi, merekstrukturisasi mesin dan industrinya sehingga mampu mengolah kayu bundar jenis cepat tumbuh (fast growing species atau FGS) atau kayu lunak yang dihasilkan dari pembangunan hutan tanaman berbasis kerakyatan. Kemitraan merupakan solusi kepastian pasokan kayu dengan kendala keterbatasan lahan yang dimiliki oleh INPAK. Hubungan kemitraan antara industri pengolahan kayu bersama rakyat untuk membangun hutan tanaman (Kibarhut) di Pulau Jawa teridentifikasi dilakukan 10 unit INPAK (kapasitas produksi $>6.000 \mathrm{~m}^{3} /$ tahun dan tersebar di 4 provinsi).

Berdasarkan hal tersebut, dugaan bahwa keberlangsungan Kibarhut dapat terwujud karena menghasilkan komoditas yang memiliki keunggulan (daya saing) guna memenuhi pasar kayu bundar menjadi menarik untuk dikaji. Penelitian ini dilakukan untuk mengetahui keunggulan kompetitif dan komparatif Kibarhut di Pulau Jawa. Keunggulan kompetitif menunjukkan kemampuan sistem usaha (Kibarhut) dalam mengalokasikan sumberdaya yang dipergunakan berdasarkan harga privat secara efisien, sedangkan keunggulan kometitif efisiensi alokasi sumberdaya berdasarakan harga sosial/ekonomis (Pearson et al., 2005). Keunggulan tersebut dikaji implikasinya terhadap peluang ekspor komoditas hasil KIBARHUT, yaitu kayu bundar jenis cepat tumbuh.

\section{METODOLOGI}

\section{A. Lokasi dan waktu penelitian}

Penelitian dilakukan pada bulan April - Oktober 2008 berlokasi di Kec. Sukaraja (Tasikmalaya, Jawa Barat), Kec. Bawang (Batang, Jawa Tengah) dan Kec. Krucil (Probolinggo, Jawa Timur). Pemilihan lokasi berdasarkan kriteria (i) terdapat 3 INPAK yang berbeda di ketiga lokasi tersebut, yaitu PT. Bineatama Kayone Lestari (BKL) di Sukaraja, PT. Sumber Graha Sejahtera (SGS) di Bawang, dan PT. Kutai Timber Indonesia (KTI) di Krucil; (ii) pemilikan lahan yang dimanfaatkan untuk membangun hutan Kibarhut, yaitu (i) Kibarhut pada lahan milik di Sukaraja, Bawang, dan Krucil; (ii) Kibarhut pada lahan Negara/bukan lahan milik di Sukaraja dan Krucil.

\section{B. Data}

Data yang dikumpulkan adalah data primer dan sekunder meliputi data kuantitatif dan 
kualitatif. Pengumpulan data informasi obyektif sesuai kebutuhan dilakukan dengan pendekatan: penelusuran dokumen, wawancara, observasi lapangan, dan focus group discussion (FGD).

\section{Metode Analisis}

Untuk menganalisis keadaan ekonomi dari sudut usaha swasta (private profit), sekaligus memberi ukuran tingkat kinerja ekonomi usaha atau keuntungan sosial (social profit) adalah dengan "matriks analisis kebijakan" (policy analysis matrix - PAM). Analisis PAM digunakan untuk mengkaji keunggulan kompetitif dan komparatif usaha Kibarhut di Pulau Jawa. Pearson et al. (2005) menyatakan bahwa keunggulan (daya saing) suatu sistem usahatani diukur dari tingkat efisiensi usaha berdasarkan harga privat (keunggulan kompetitif) dan berdasarkan harga sosial (keunggulan komparatif). Analisis menggunakan model PAM yang dikembangkan Pearson et al. (2005).

Analisis empiris dalam PAM meliputi 3 (tiga) analisis yang direpresentasikan dalam Tabel PAM, yaitu analisis privat, analisis sosial, dan analisis dampak divergensi. Analisis privat dilakukan menggunakan pendekatan harga pasar (private) dan analisis sosial menggunakan harga efisiensi atau harga bayangan (Gittinger, 1982; Nair, 1993), sehingga menunjukkan bahwa perhitungan dalam matriks PAM mencakup analisis finansial dan ekonomi. Hasil PAM juga mempunyai keluaran yang dapat dipergunakan untuk menganalisis peluang ekspor kayu hasil Kibarhut di Pulau Jawa. Analisis teoritis dan grafis terhadap perubahan supply dan demand (Henderson dan Quandt, 1980; Sugiarto et al., 2002; Soekartawi, 2002) kayu bundar jenis FGS dilakukan untuk melengkapi evaluasi keunggulan Kibarhut. Model grafis dibuat dengan asumsi bahwa bertambah/berkurangnya pasokan kayu bundar jenis FGS di dunia (karena kurva supply yang bergeser ke kanan/kiri) berdampak terhadap menurun/ meningkatnya harga kayu, khususnya sengon.

\section{Asumsi}

Asumsi yang dipergunakan dalam penelitian adalah (i) tingkat diskonto atau suku bunga finansial sebesar 15\% dan suku bunga sosial adalah 18\% yang ditetapkan berdasarkan data dari BI (website http://www.bi.go.id/web/id/ Moneter/BI+Rate/), Bank Kredit Desa di lokasi contoh dan Pearson et al. (2005); (ii) skala usaha dianalisis pada tingkat usahatani yaitu rata-rata luasan lahan petani yang dikerjasamakan dalam rangka Kibarhut berkisar 0,162 0,384 ha; (iii) kayu FGS yang dicermati adalah jenis Sengon; (iv) harga paritas kayu dihitung dari rata-rata harga internasional kayu (US\$ 109) dengan kualifikasi FOB Manila (Philippines), kayu Sengon diameter sekitar $20 \mathrm{~cm}$ (diunduh dari website http://qualiventures_ia. en.ecplaza.net tanggal 20 Desember 2008). Komponen lainnya, yaitu semua harga input dan output (dalam rupiah), berdasarkan harga berlaku pada tahun penelitian (2008), dengan asumsi harga konstan selama daur/pelaksanaan Kibarhut.

\section{HASIL DAN PEMBAHASAN}




\section{A. Keunggulan Kompetitif dan Komparatif Kibarhut di Pulau Jawa}

Hasil perhitungan PAM usaha Kibarhut di Pulau Jawa pada tingkat usaha tani disajikan pada Tabel 1.

Tabel (Table) 1. Ringkasan PAM Kibarhut di Pulau Jawa (PAM's Summary of Kibarbut in Java Island)

Tabel 1 menunjukkan bahwa KibarhutT di Pulau Jawa menghasilkan keuntungan privat positif (PP > 0) untuk semua tipe. PP bernilai positif membuktikan bahwa Kibarhut

\begin{tabular}{|c|c|c|c|c|c|c|}
\hline \multirow{2}{*}{$\begin{array}{l}\text { Nilai } \\
\text { (Ratio) }\end{array}$} & \multicolumn{3}{|c|}{$\begin{array}{c}\text { Lahan milik } \\
\text { (Private-owned land) }\end{array}$} & \multicolumn{2}{|c|}{$\begin{array}{l}\text { Lahan negara (State property } \\
\text { (non-private land)) }\end{array}$} & \multirow{2}{*}{$\begin{array}{c}\text { Rerata } \\
\text { (Average })\end{array}$} \\
\hline & Bawang & Sukaraja & Krucil & Sukaraja & Krucil & \\
\hline PP & 2.498 .631 & 2.672 .323 & 2.836 .537 & 3.699 .251 & 1.957 .878 & --- \\
\hline SP & 3.942 .644 & 4.563 .818 & 6.696 .958 & 5.092 .709 & 4.274 .046 & --- \\
\hline OT & (964.836) & $(1.517 .669)$ & $(3.008 .470)$ & (1.087.407) & $(1.392 .713)$ & --- \\
\hline IT & 254.397 & 28.921 & 336.391 & 51.117 & 464.978 & --- \\
\hline FT & 224.780 & 344.904 & 515.560 & 254.934 & 521.477 & --- \\
\hline NT & $(1.444 .013)$ & $(1.891 .494)$ & $(3.860 .420)$ & (1.393.458) & $(2.316 .168)$ & --- \\
\hline PCR & 0,710 & 0,670 & 0,803 & 0,567 & 0,859 & 0,701 \\
\hline DRC & 0,602 & 0,530 & 0,623 & 0,474 & 0,729 & 0,572 \\
\hline NPCO & 0,924 & 0,875 & 0,856 & 0,902 & 0,933 & 0,891 \\
\hline NPCI & 1,114 & 1,014 & 1,110 & 1,036 & 1,128 & 1,083 \\
\hline PC & 0,644 & 0,591 & 0,424 & 0,726 & 0,470 & 0,577 \\
\hline
\end{tabular}

Keterangan (Remarks): $\mathrm{PP}=$ keuntungan privat (private profit); $\mathrm{SP}=$ keuntungan sosial (social profit); OT $=$ transfer output (output transfer); IT = transfer input (input transfer); FT = transfer faktor (factor transfer); NT = transfer bersih (net transfer); $\mathrm{PCR}=$ rasio biaya private (private cost ratio); DRC $=$ rasio biaya sumberdaya domestic (domestic resources cost ratio); NPCO $=$ koefisien proteksi output nominal (nominal protection coeeficient on tradabale output); NPCI = koefisien proteksi input nominal (nominal protection coefficient on tradable input); PC = koefisien keuntungan (profitability koefisien)

adalah usaha yang memiliki efisiensi secara finansial atau keunggulan kompetitif sehingga mampu untuk berekspansi. Berdasarkan harga sosial, Kibarhut menghasilkan keuntungan sosial positif ( $\mathrm{SP}>0$ ) untuk semua tipe atau memiliki keunggulan komparatif.

Keunggulan kompetitif dan komparatif juga dapat dikaji dengan nilai PCR dan DRC. Tabel 1 menunjukkan bahwa semua tipe pada Kibarhut mempunyai PCR $<1$ dengan nilai rata-rata 0,701. Nilai PCR tersebut menunjukkan bahwa untuk meningkatkan nilai tambah output sebesar 1 satuan pada harga privat maka, diperlukan tambahan biaya faktor domestik kurang dari satu satuan atau sebesar rata-rata 0,701 satuan. Rasio PCR $<1$ tersebut juga memperlihatkan bahwa Kibarhut memiliki keunggulan secara kompetitif, dan keunggulan tersebut meningkat dengan semakin kecilnya nilai PCR yang berarti semakin efisien secara finansial. Berdasarkan kriteria tersebut, maka Tipe 3 Sukaraja mempunyai keunggulan kompetitif terbaik dibandingkan tipe lainnya.

Kibarhut mempunyai DRC $<1$ dengan nilai rata-rata 0,572. Rasio DRC menunjukkan bahwa untuk menghasilkan komoditas kayu FGS melalui Kibarhut membutuhkan biaya 
sumberdaya domestik rata-rata 57,2\% terhadap biaya impor yang dibutuhkan. Dengan kata lain, untuk menghasilkan setiap US\$ 1.00 dari hasil kayu jenis FGS maka Kibarhut hanya membutuhkan biaya domestik US\$ 0,572 untuk memproduksinya. DRC juga memperlihatkan bahwa Kibarhut memiliki keunggulan secara komparatif. Keunggulan tersebut semakin meningkat dengan semakin kecilnya DRC, yang berarti mempunyai keunggulan komparatif yang semakin tinggi. Berdasarkan kriteria tersebut, maka Tipe 3 Sukaraja mempunyai keunggulan komparatif terbaik dibandingkan tipe lainnya.

Pada sisi output produksi, output transfer atau OT merupakan selisih antara penerimaan berdasarkan harga privat dengan penerimaan berdasarkan harga sosial. OT pada semua tipe Kibarhut mempunyai nilai negatif. OT bernilai negatif berarti konsumen (INPAK) membeli dan produsen menerima harga yang lebih rendah dari harga seharusnya, sehingga pengelola hutan (produsen) seolah-olah (implisit) dibebani pajak/transfer sumberdaya yang mengurangi keuntungan sistem usaha Kibarhut di Pulau Jawa. Melengkapi analisis output, maka pencermatan NPCO (nominal protection coefficient on tradable output) dilakukan guna menganalisis proteksi/kebijakan pemerintah yang diberikan. NPCO yang diperoleh adalah < 1 dengan rata-rata sebesar 0,891. Nilai tersebut menunjukkan bahwa harga domestik kayu Sengon di Pulau Jawa adalah lebih rendah dari harga paritasnya, dan tidak ada policy transfer yang diterima produsen atau pengelola hutan Kibarhut.

Pada sisi input produksi, Kibarhut di Pulau Jawa menghasilkan input transferatau IT yang positif (IT > 0), karena harga privat untuk input tradable adalah lebih tinggi dibandingkan harga sosialnya. Perbandingan kedua nilai tersebut disebut NPCI, dan menghasilkan nilai yang lebih dari satu. NPCI > 1 tersebut karena harga pupuk yang dibayarkan petani lebih tinggi (berkisar 16,7 - 33,3\%) daripada harga pupuk subsidi pemerintah. Dampaknya adalah penggunaan input tradable (pupuk an-organik dan obat-obatan) yang sangat rendah dan terbatas. Input umumnya dipergunakan dalam proses produksi komoditas non kayu (tanaman hortikultur) yang ditanam secara tumpangsari pada awal daur tanaman kayu.

Harga pembelian pupuk oleh petani yang cenderung lebih tinggi dari harga pupuk subsidi pemerintah tersebut menjadikan seolah-olah komoditas tersebut dibebani pajak oleh kebijakan yang ada. Karenanya biaya-biaya yang dikeluarkan petani adalah melebihi jumlah subsidi yang diterima atas input tradable tersebut. Hal tersebut banyak ditemukan pada berbagai kasus sistem usahatani di Indonesia, sebagaimana diungkapkan Anapu et al., Aji, Budastra dan Dipokusumo, Pellokila et al., dan Zakaria et al. dalam Pearson et al. (2005). Pada sisi lain, kondisi tersebut menunjukkan adanya penggunaan input domestik yang tidak diperdagangkan di pasaran dunia (sumberdaya lokal atau factor domestic) yang lebih besar oleh petani pada pelaksanaan Kibarhut di Pulau Jawa.

Besaran yang menunjukkan perbedaan antara harga privat dan harga sosial yang diterima produsen kayu Sengon Kibarhut untuk pembayaran faktor produksi yang tidak diperdagangkan disebut factortransfer (FT). FT bernilai positif karena adanya perbedaan antara perhitungan privat dan sosial dalam hal biaya modal serta kewajiban yang dibebankan pemerintah kepada pelaku usaha, termasuk pengenaan pajak dan subsidi bunga yang dimasukkan dalam perhitungan harga privat tetapi tidak dimasukkan dalam perhitungan harga sosial.

Hasil PAM kelembagaan Kibarhut juga menunjukkan rasio keuntungan bersih yang diterima produsen terhadap keuntungan bersih secara sosial (yaitu profitability coefficient atau PC) adalah sebesar rata-rata 0,577. Artinya keuntungan yang diterima produsen atau petani hutan Kibarhut adalah lebih kecil yaitu hanya memperoleh $57,7 \%$ dari yang seharusnya karena ada surplus sebesar $42,3 \%$ yang dinikmati oleh konsumen komoditas yang dihasilkan dari 
kelembagaan Kibarhut di Pulau Jawa. Hasil ini menunjukkan bahwa kebijakan pemerintah saat ini belum memberikan insentif bagi pembangunan hutan Kibarhut dan tidak ada perlindungan (policy transfer) kepada petaniKibarhut.

\section{B. Analisis Peluang Ekspor Kayu Hasil Kibarhut di Pulau Jawa}

Kebijakan pemerintah saat ini tidak memperkenankan (melarang) ekspor kayu bundar (KB). Pelarangan ekspor KB telah dimulai tahun 1980 dengan diterbitkannya Surat Keputusan Bersama Tiga Menteri (SKB 3 Menteri) dan SKB 3 Dirjen mengenai kewajiban penyediaan kayu untuk industri dalam negeri dikaitkan dengan ekspor KB. SKB efektif diberlakukan pada tahun 1985.

Guna menghindari desakan dan intervensi internasional seiring derasnya arus liberalisasi perdagangan dunia, maka pemerintah mencabut larangan ekspor KB dan menerapkan pajak ekspor yang tinggi sebesar US\$500-4,800 per $\mathrm{m}^{3} \mathrm{~KB}$ sejak Juni 1992, dan menurunkannya menjadi $10 \%$ dari harga patokan ekspor pada Desember 2000 (Simangunsong, 2004). Kebijakan tersebut tidak bertahan lama karena kemudian larangan ekspor KB kembali diberlakukan dengan terbitnya SKB Menteri Kehutanan dan Menteri Perindustrian dan Perdagangan pada Oktober 2001 dan kebijakan larangan eskpor tersebut masih berlaku sampai dengan saatini.

Secara teoritis, kebijakan pemerintah untuk melarang eskpor KB (khususnya jenis cepat tumbuh/FGS atau kayu dari hutan tanaman) menyebabkan pasar KB tertutup dan terbatas pada kebutuhan lokal. Secara grafis (Gambar 1), adanya larangan eskpor KB yang dilakukan oleh suatu negara (dalam hal ini adalah Indonesia) menyebabkan pasokan KB di dunia menjadi berkurang, sehingga menjadikan harga meningkat (pasokan dunia berkurang sebesar AB atau selisih $\boldsymbol{Q}_{w}^{\boldsymbol{D}}$ dan $\boldsymbol{Q}_{\mathrm{w}}^{\boldsymbol{s}}$, yang sekaligus menjadi excess supply KB jenis FGS di dalam negeri). Harga $\mathrm{KB}$ di pasar dunia menjadi lebih tinggi dibandingkan harga di dalam negeri (Pw $>$ Pd).

Secara teoritis, jika pemerintah mengeluarkan kebijakan (ekstrim) membolehkan ekspor KB jenis FGS (Sengon) tanpa adanya tarif bea keluar, maka harga domestik 


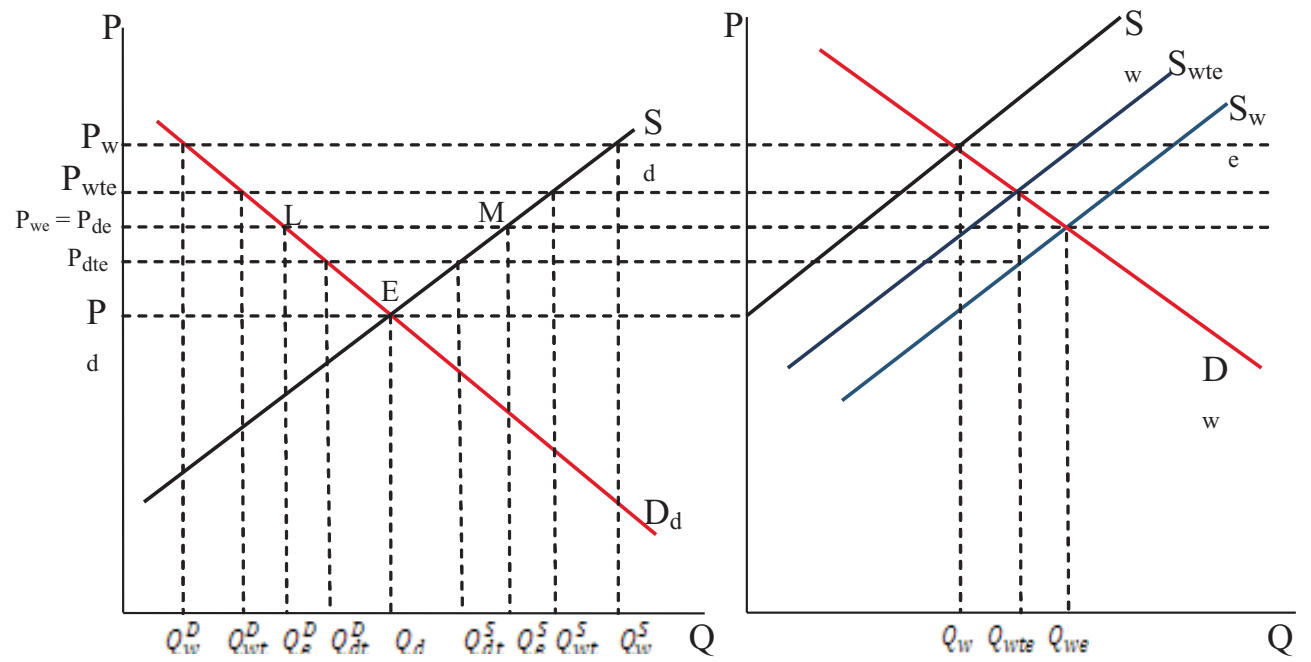

A. Pasar domestik KB jenis FGS (Domestic market of FGS' log)
B. Pasar dunia KB jenis FGS

(World market of FGS's Log)

Gambar(Figure) 1. Pengaruh kebijakan ekspor terhadap pasar KB jenis FGS (Impacts of exportpolicy on market of $F G S^{\prime}$ s $\log$ )

Keterangan (Remarks): $\mathrm{D}=$ garis permintaan $($ demand $) ; \mathrm{Dd}=$ permintaan dalam negeri; $\mathrm{Dw}=$ permintaan dunia; $\mathrm{S}$ = garis penawaran $($ supply); $\mathrm{Sd}=$ penawaran dalam negeri; $\mathrm{Sw}=$ permintaan luar negeri; Swte $=$ penawaran pada tingkat Pwte $\mathrm{P}=$ harga (price) $\mathrm{Pd}=$ harga dalam negeri; $\mathrm{Pw}=$ harga dunia; Pwte = harga dunia dikurangi biaya transportasi; Pdte $=$ harga domestik ditambah pajak; Pwe $=$ Pde $=$ harga domestik setara harga dunia; $\mathrm{Q}=$ jumlah $($ quantity) $; \mathrm{L}=$ jumlah permintaan dan $\mathrm{M}=$ jumlah penawaran pada $\mathrm{Pde}=$ Pwe sehingga terjadi kelebihan penawaran (excess supply)

merangkak naik secara ekstrim, sehingga setara harga dunia $\left(\mathrm{P}_{\mathrm{de}}=\mathrm{P}_{\mathrm{we}}\right)$. Pada titik dimaksud, jumlah yang mungkin diekspor adalah sebesar excess supply yang terjadi pada tingkat harga tersebut (yaitu sebesar LM atau selisih $\boldsymbol{Q}_{\mathrm{e}}^{D}$ dan $\boldsymbol{Q}_{\mathrm{e}}^{s}$ ). Ekspor KB terus dilakukan, sampai dengan selisih harga dunia dan harga domestik adalah sama dengan biaya pengangkutannya dari Indonesia ke negara pengimpor, ditambah biaya-biaya lainnya yang dikenakan terhadap barang ekspor tersebut. Ekspor dihentikan ketika tidak ada lagi perbedaan harga paritas dan harga pasar (lokal) di tingkat pabrik.

Dengan demikian, pasokan KB di pasar internasional bertambah banyak (dari Qw ke Qwe), sehingga menggeser kurva supply ke kanan (dari Sw ke Swe). Pada kondisi tersebut, produsen (pengelola hutan) memperoleh manfaat (gains) terbesar, konsumen domestik (INPAK) menderita kerugian (consumers' loss), dan pemerintah memperoleh sedikit tambahan pendapatan (dari PPH, PPh, dan PNBP tetapi tidak dari bea keluar), serta terjadi perolehan devisa dari adanya ekspor KB tersebut.

Widyantoro (2005) mengungkapkan dalam kondisi tersebut, maka naiknya harga KB yang terlalu besar (misal mencapai lebih dari 30\%) meningkatkan pasokan kayu dunia 
sehingga kurva bergeser ke kanan. Dampaknya adalah terjadi penurunan surplus konsumen yang lebih besar dibandingkan peningkatan surplus produsen dan penerimaan pemerintah. Selain itu, ekonomi domestik juga ikut turun akibat dari surplus konsumen yang turun lebih besar daripada peningkatan penerimaan pemerintah dan penerimaan devisa. Karenanya kebijakan membuka keran ekspor (secara bebas) dalam jangka pendek tidak memberikan insentif, sehingga perlu ditempuh suatu paket kebijakan yang mencakup juga upaya memperbanyak industri (industri pulp and paper atau industri pengolahan kayu lainnya sebagai alternatif). Secara intuitif, banyaknya industri memberikan peluang berkembangnya dan tumbuhnya motivasi pengelolaan dan pembangunan hutan, karena pembeli KB jenis FGS semakin banyak dan pasar semakin kompetitif. Untuk menghambat kenaikan harga yang terlampau tinggi dan menstabilkan pasokan INPAK di dalam negeri sekaligus peningkatan pendapatan negara, maka pemerintah dapat menerapkan pajak/bea keluar sebesar tx terhadap KB jenis FGS. Adanya pajak mengurangi ekspor sampai pada tingkat dimana harga domestik ditambah pajak (Pdte) dan biaya-biaya lain yang dikenakan terhadap barang ekspor adalah setara harga di pasar internasional (Pwte) setelah dikurangi biaya transportasi. Pasokan internasional sedikit berkurang dibandingkan sebelumnya sehingga kurva supply hanya bergeser ke Swte.

Temuan penelitian menunjukkan hasil yang sejalan dengan kajian teoritis tersebut diatas. Data penelitian menunjukkan bahwa harga (pasar) domestik di tingkat (pintu) pabrik rata-rata Rp 650.000 setara US\$70,35 per $\mathrm{m}^{3}$ (US\$1 = Rp 9.240). Rata-rata harga dunia adalah US\$ 109 atau harga paritasnya di tingkat pabrik senilai rata-rata Rp 802.432 atau US\$ 86,84. Terdapat perbedaan (disparitas) antara harga dunia ( $\mathrm{Pw}$ ) sebesar 35,8\% dengan harga pasar domestik (Pd), atau disparitas sebesar 25,5\% antara harga paritasnya dibandingkan $\mathrm{P}_{\mathrm{d}}{ }^{1}$.

Kondisi tersebut menunjukkan bahwa kebijakan pemerintah belum memberikan insentif bagi pelaksanaan Kibarhut di Pulau Jawa dan tidak ada perlindungan atau proteksi diterima petani atau produsen kayu Kibarhut. Harga output (kayu Sengon) hasil Kibarhut di pasar domestik yang masih lebih rendah dibandingkan harga dunianya juga ditunjukkan dari nilai OT yang negatif dan NPCO $<1$ pada hasil PAM di Tabel 1. Kebijakan saat ini juga menyebabkan tidak adanya pendapatan (government revenue) diterima pemerintah dalam bentuk pungutan ekspor/PE atau bea keluar (sejak tahun 2008, istilah PE diganti menjadi tariff bea keluar yang besarnya ditentukan Menteri Keuangan).

Adanya selisih harga tersebut secara sederhana dianggap memadai untuk membiayai berbagai biaya-biaya terkait ekspor KB, sebagaimana dinyatakan Widyantoro (2005) bahwa jika disparitas harga kayu mencapai $>30 \%$ maka transaksi ekspor dapat dilakukan. Pada sisi lain, Kibarhut di Pulau Jawa terbukti mampu mengalokasikan sumberdaya secara efisien, mempunyai keunggulan kompetitif dan komparatif. Hasil tersebut menunjukkan bahwa KIBARHUT di Pulau Jawa memiliki daya saing dan mempunyai peluang ekspor, karena mampu menghasilkan harga FOB untuk kayu Sengon yang memiliki daya saing di pasar

\footnotetext{
${ }^{1}$ Harga dunia tidak dapat secara langsung dijadikan patokan, sehingga perhitungan PAM dengan menggunakan harga paritasnya. Penggunaan harga paritas suatu komoditas yang tradable adalah harga sosial yang diduga dari harga barang sejenis (comparable) di pasar internasional, yaitu harga impor (cost insurance freight - CIF) untuk komoditas impor dan harga ekspor (free on board - FOB) untuk komoditas ekspor. Harga paritas berdasarkan harga internasional dengan memperhitungkan biaya kapal, asuransi, dan nilai kurs, serta biaya karantina, biaya pelabuhan dan angkutan ke pelabuhan, sehingga menjadi harga FOB di Indonesia. Artinya, harga paritas diperbandingkan pada lokasi, waktu, kualitas dan bentuk yang sama).
} 
ekspor.

Secara sederhana jika transaksi ekpor KB jenis FGS (kayu sengon dari Pulau Jawa) diperkenankan, maka terdapat kemungkinan bagi pemerintah mengenakan maksimal 12,75\% bea keluar pada tariff atau harga patokan eskpor sekitar US\$109. Bea keluar tersebut dihitung berdasarkan disparitas di pintu pabrik/eksportir sebesar 25,5\% dikurangi 12,75\% pajak/retribusi yang harus dibayar eksportir (yaitu PPN=10\%, PPh pasal $22=2,5 \%$, dan PNBP Rp 50.000/kontainer, sedangkan tarif bea keluar kayu bundar adalah belum diatur karena dilarang untuk diekspor). Jika tariff/HPE ditetapkan lebih rendah dari US\$109, maka bea keluar dapat dikenakan dengan tarif lebih tinggi dari 12,75\% dan begitu juga sebaliknya.

Pada kondisi tersebut, konsumen dan produsen memperoleh surplus, walaupun surplus terbesar tetap diperoleh produsen (pengelola hutan), sedangkan pemerintah memperoleh pendapatan (government revenue) dari peningkatan provisi sumberdaya hutan (PSDH) dan peningkataan tarif bea keluar sebesar selisih $Q_{d t}^{D}$ dan $Q_{d t}^{S}$ dikalikan besarnya pajak.

Pengenaan bea keluar sebesar tersebut masih dalam batas kewajaran, sebagaimana diungkapkan Astana (2005) bahwa tarif bea keluar optimal berkisar 15 - 30\% dari harga patokan ekspor. Bea keluar terlalu tinggi menyebabkan harga domestik kayu jenis FGS tertekan dan bernilai jauh di bawah harga dunianya, sedangkan bea keluar terlalu rendah menyebabkan harga kayu di dalam negeri melonjak terlampau tinggi sehingga mengganggu pasokan kayu bagi industri dalam negeri. Pada sisi lain, pengenaan tarif bea keluar juga harus memperhitungkan kemungkinan adanya biaya sertifikasi dan uji laboratorium yang diwajibkan untuk transaksi internasional produk kayu (di antaranya adalah SPS dan fumigasi), biaya siluman (invicible cost) di pelabuhan, serta resiko pemasaran internasional seperti nilai tukar, krisis keuangan, dan tingginya nilai jaminan asuransi.

\section{KESIMPULAN DAN SARAN}

\section{A. Kesimpulan}

Kelembagaan kemitraan antara industri pengolahan kayu dan rakyat untuk membangun hutan (KIBARHUT) di Pulau Jawa terbukti memiliki keunggulan kompetitif dan komparatif. Keunggulan tersebut menghasilkan komoditas yang mempunyai peluang ekspor karena mampu menghasilkan kayu dengan harga FOB yang kompetitif di pasar internasional.

\section{B. Saran}

Kebijakan ekspor kayu jenis FGS (khususnya Sengon) hasil Kibarhut (atau hutan tanaman) di Pulau Jawa adalah dimungkinkan karena adanya disparitas harga lokal dibandingkan harga paritasnya di pintu pabrik, sehingga mampu membiayai biaya dan pungutan (pajak/retribusi) pada pemasaran ekspor dan membayar tarif bea keluar. Kebijakan lainnya yang perlu dipertimbangkan adalah memperbanyak industri pengolahan kayu yang mempunyai kemampuan memanfaatkan kayu jenis FGS. Secara intuitif, banyaknya industri memberikan peluang berkembang dan tumbuhnya motivasi pelaku hutan untuk membangun hutan, karena pembeli (konsumen) kayu semakin banyak dan pasar semakin kompetitif.

\section{DAFTAR PUSTAKA}


Astana A. 2005. Analisis Kebijakan Ekspor Kayu Bulat dari Hutan Tanaman Acacia Mangium. Jurnal Penelitian Sosial dan Ekonomi Kehutanan 2(2): 115-135. Bogor: Badan Litbang Kehutanan.

Gittinger JP. 1982. Economic Analysis of Agricultural Projects. Second Edition. The Economic Development Institute of the World Bank. The Johns Hopkins University Press: Baltimore and London.

Henderson JM dan Quandt RE. 1980. Microeconomic Theory: a Mathematical Approach. Tokyo: McGraw-Hill International Book Company.

Kartodhihardjo H. 2002. Re-orientasi Sistem Perijinan dan Pengesahan: Menuju Perubahan Budaya Pengelolaan Hutan Skala Besar. Seri Kajian Komuniti Forestri (Komuniti Forestri di Tengah Gempuran Globalisasi) 5 (V)..

Moniaga, S. 1993. Toward Community-Based Forestry and Recognition of Adat Property Rights in the Outer Islands of Indonesia. Chapter 10 dalam Fox, J. 1993. Legal Frameworks for Forest Management in Asia: Case Studies of Community/State Relations. Honolulu, USA: East-West Center.

Nair PKR. 1993. Economic Consideration. Dalam An Introduction to Agroforestry. Kluwer Publishing: the Netherlands. pp 385-411.Najiyati et al, 2005.

Nicholson W. 2002. Mikroekonomi Internmediate dan Aplikasinya. Bayu Mahendra dan Abdul Aziz, penerjemah. Jakarta: PT. Penerbit Erlangga. Terjemahan dari: Intermediate Economics and Its Application. 8th Edition.

Pearson S, Gotsch S, Bahri S. 2005. Aplikasi Policy Analysis Matrix pada Pertanian Indonesian. Jakarta: Development Alternatives Inc. - Food Policy Support Activity (DAI - FPSA) Jakarta dan Yayasan Obor Indonesia.

Simangunsong BCH.2004. The Economic of Performance of Indonesia's Forest Sector in the Period 1980 - 2002. Website http://www.forestandtradeasia.org/files/ Economic $\% 20$ Performance $\% 20$ of $\% 20$ Indonesia $\% 20$ Forest $\% 20$ Sector $\% 20$ in $\% 20$ t he\%20period\%201980\%20-\%202002.pdf [diunduh 21 Juni 2009).

Sugiarto, Herlambang T, Brastoro, Sudjana R, Kelana S. 2002. Ekonomi Mikro: Sebuah Kajian Komprehensif. Jakarta: PT. Gramedia Pustaka Utama.

Soekartawi, 2002. Prinsip Dasar Ekonomi Pertanian: Teori dan Aplikasi (edisi 2). Jakarta: RajaGrafindo Persada.

Widyantoro B. 2005. Ekonomi Industri Pulp dan Kertas Indonesia: Suatu Analisis Simulasi Kebijakan dan Tekanan Internasional [disertasi]. Bogor: Sekolah Pascasarjana, Institut Pertanian Bogor (tidak dipublikasikan). 